\title{
Disappearing giants: a review of threats to freshwater megafauna
}

\author{
He, F., Zarfl, C., Bremerich, V., Henshaw, A.J., Darwall, W., Tockner, K. and Jähnig, S.C.
}

Journal: WIREs Water (accepted for publication January 2017)

Article type: Overview

\begin{abstract}
Charismatic megafauna species may act as both flagship and umbrella species. They influence local environments and biotas, determine related ecosystem processes and functions, and are associated with high levels of biodiversity. However, the intrinsic characteristics of megafauna species including long lifespan, large body size, sparseness and/or rarity, late maturity and low fecundity, as well as high market value, make them very prone to extinction. Up to now, scientific interest and conservation efforts have mainly focused on terrestrial and marine megafauna, while freshwater species have received comparatively little attention, despite evidence suggesting that freshwaters are losing species faster than marine or terrestrial realms. The high susceptibility of freshwater megafauna to multiple threats, coupled with immense human pressure on freshwater ecosystems, places freshwater megafauna amongst the most threatened species globally. The main threats include overexploitation, dam construction, habitat degradation, pollution and species invasion. These threats increase mortality, decrease productivity and reduce fitness, causing the decline of populations and the extinction of freshwater megafauna species. Given the essential ecological and biological roles of freshwater megafauna, further research should focus on their distribution patterns, extinction risks and population dynamics, thereby improving the knowledge base for conservation planning. Finally, freshwater megafauna-based conservation strategies may raise public awareness for freshwater conservation and therefore benefit a broader range of freshwater species and functions.
\end{abstract}




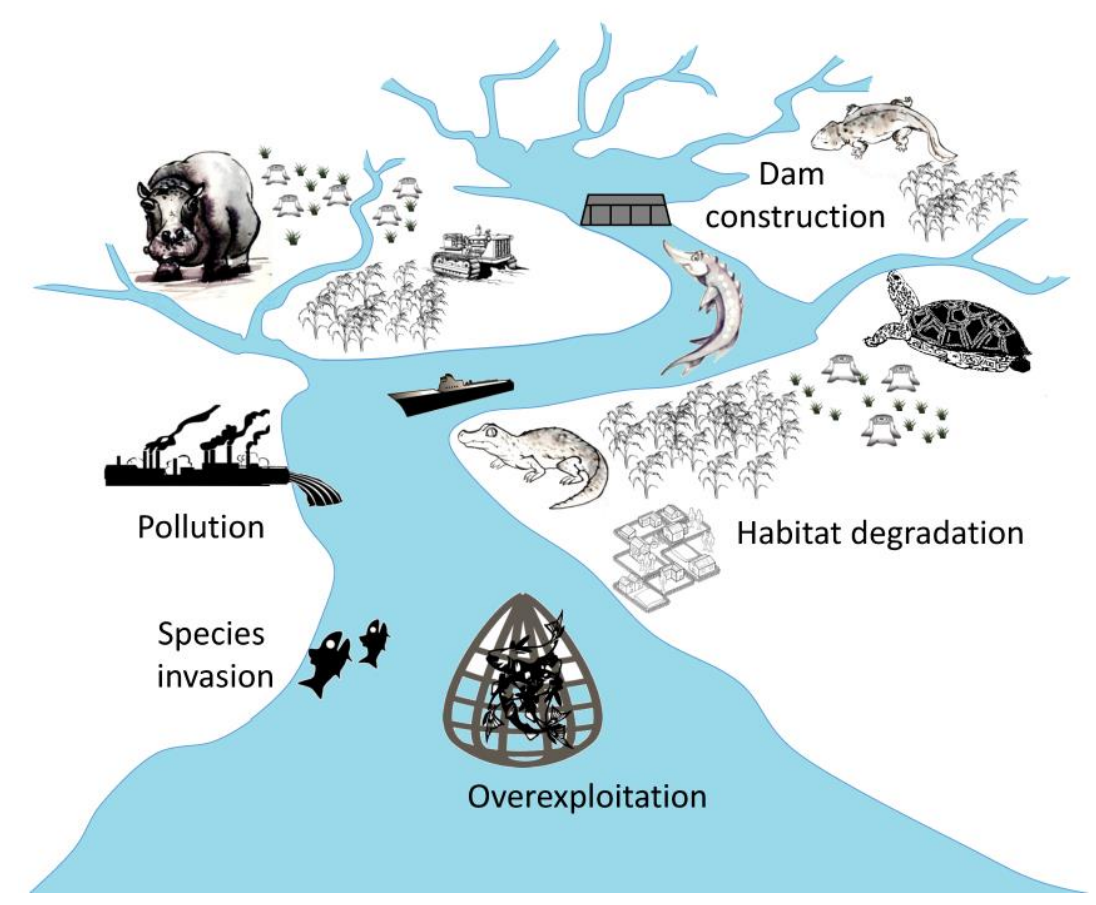

Freshwater megafauna are facing a wide range of threats that could lead to the decline of populations, reduction of genetic variability, and species extinction.

\section{INTRODUCTION}

Animals are classified according to various characteristics and traits, including size. The term megafauna refers to disproportionally large-bodied animals and is often associated with prehistoric large terrestrial vertebrates weighting more than $44 \mathrm{~kg}$ (ca. 100 pounds) ${ }^{1,2}$. More recently, however, the concept of megafauna has been extended beyond a uniform weight threshold ${ }^{3-5}$, to cover both extinct and extant species in terrestrial, marine and freshwater ecosystems ${ }^{6-8}$.

Megafauna species receive significant attention due to their charismatic nature and their susceptibility to extinction ${ }^{9-11}$. They are, therefore, often used as flagship and umbrella species, promoting public awareness ${ }^{12}$ and stimulating funding for environmental conservation ${ }^{13}$, ${ }^{14}$. For instance, the "big five" (i.e. buffalo, elephant, lion, leopard, and rhinoceros) are important flagship species for sub-Saharan Africa, having secured strong public attention and subsequent support ${ }^{15}$. Recently, research on megafauna has increased (Figure 1), but with the scientific interest and conservation efforts mainly focusing on terrestrial and marine ecosystems. In contrast, freshwater megafauna remain underrepresented both in science and in public awareness ${ }^{16}$. At the same time, freshwaters are among the most threatened ecosystems globally; with species populations declining much faster than in terrestrial and marine realms ${ }^{17-19}$. Furthermore, the concept of megafauna is rarely considered in freshwater research and conservation. Indeed, we still lack an official definition of freshwater megafauna. In the present review, we define freshwater megafauna as all animals 
with a body mass of at least $30 \mathrm{~kg}$ that spend an essential part of their life in freshwater or brackish ecosystems. Based on a $30 \mathrm{~kg}$ threshold, freshwater megafauna species include representatives of fishes, reptiles, mammals and amphibians.

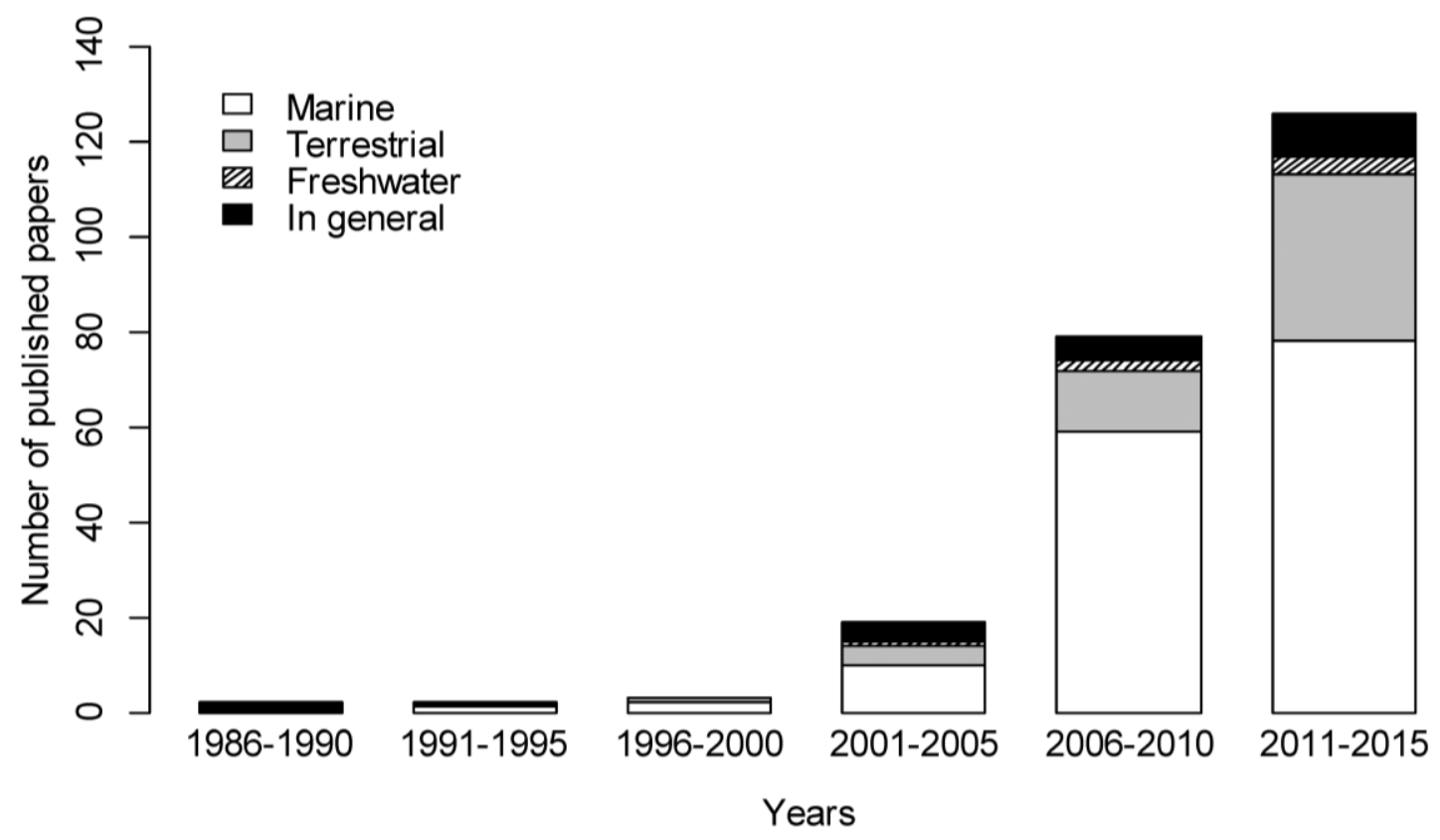

FIGURE 1. Numbers of publications focused on megafauna in different ecosystems (for details on the underlying methodology see Supporting Information).

Megafauna species shape ecosystems and their related processes, often representing key ecosystem engineers ${ }^{20-22}$. For example, beavers (the American Beaver, Castor canadensis and the Eurasian Beaver, Castor fiber) alter stream morphology through dam building, thereby changing hydrological and biogeochemical processes, as well as affecting in-stream and riparian biotas ${ }^{23-25}$. The American Alligator (Alligator mississippiensis) modifies the Everglades landscape by creating and maintaining small ponds which, in turn, provide habitat and refugia for many additional plants and small animals ${ }^{26}$. Freshwater megafauna may also increase the nutrient flow between freshwater, terrestrial and marine ecosystems. For instance, anadromous freshwater megafauna (e.g. the Atlantic salmon, Salmo salar and the Chinook Salmon, Oncorhynchus tshawytscha) transfer large amounts of nutrients from the ocean to freshwaters and finally to terrestrial systems ${ }^{27,28}$, shaping productivity and food web dynamics in river and riparian systems.

Many freshwater megafauna species are top predators. Their extirpation would often lead to marked effects on local community structure through trophic cascades. For examples, the loss of large predatory fish might release small planktivorous species from predation, thus altering consumption pressures on zooplankton and phytoplankton ${ }^{29}$. Moreover, freshwater megafauna may create habitat for other species, such as through the creation of ponds and holes by hippopotamus or crocodilians so providing dry-season refugia for many fish species ${ }^{22,26}$. The decline of Brown Trout (Salmo trutta), mainly due to habitat fragmentation, threatens the Freshwater Pearl Mussel (Margaritifera margaritifera), because it is an important host for the parasitic mussel larvae ${ }^{30}$. These 
few selected examples emphasize the potentially far-reaching ecological and biological consequences of freshwater megafauna loss.

A high proportion of the world's freshwater megafauna species are under threat ${ }^{31-33}$. Indeed, 54\% (i.e. 84 out of 155 assessed species) of freshwater megafauna are already listed as threatened (Critically Endangered, Endangered or Vulnerable; for details see Supporting Information), based on the International Union for Conservation of Nature (IUCN) Red List of Threatened Species ${ }^{\mathrm{TM}}$ (hereafter IUCN Red List) ${ }^{34}$. Four species are Critically Endangered (Possibly Extinct), including the Chinese Paddlefish (Psephurus gladius), the world's longest freshwater fish, which has not been seen since 2003 ${ }^{35}$; the Baiji (Lipotes vexillifer), which could represent the first human-caused extinction of a cetacean species ${ }^{36}$; the Yangtze Sturgeon (Acipenser dabryanus); and the Adriatic Sturgeon (Acipenser naccarii). Today, both sturgeon species are strongly dependent on artificial stocking to maintain their populations in the wild ${ }^{37}$. 38 . The Atlantic (or Common) Sturgeon (Acipenser sturio), once the most common sturgeon species across Europe, is now restricted to the Garonne River (France) and is experiencing an ongoing decline ${ }^{39}$.

Many freshwater megafauna species inhabit remote areas and their decline or loss will often go unnoticed due to poor monitoring. For instance, despite its large size, the Freshwater Whipray (Himantura dalyensis) still lacks information on many of the threats it faces and was only recently recognized as a separate species ${ }^{40}$. Discussion on the taxonomy of Arapaima spp. is still ongoing ${ }^{41,42}$, and the assessment of Arapaima (Arapaima gigas) needs updating as it is still listed as Data Deficient on the IUCN Red List, in spite of increasing evidence that it is seriously threatened by overexploitation ${ }^{43}, 44$. Although research on the conservation status has been conducted for individual species and taxonomic groups, such as sturgeons and paddlefishes, we lack a collective overview of the threat status for all freshwater megafauna at the global scale. Intending to fill this important information gap, this paper provides a comprehensive overview of the threats facing freshwater megafauna, and of the subsequent impacts. In addition, we highlight the urgent need for great focus on the conservation of freshwater biodiversity.

\section{THREATS TO FRESHWATER MEGAFAUNA}

The loss of freshwater megafauna is mainly driven by overexploitation, dam construction, habitat degradation, pollution and species invasion, along with the compounding impacts of climate change (Table 1). The interacting and combined impacts of these threats have led to a decline in population size and range reduction for many freshwater megafauna species ${ }^{45,46}$. Although there remains a lack of understanding of the influence of climate change on freshwater megafauna, global warming and drought are likely to increase habitat degradation, further increasing direct impacts of human activities. The Freshwater Whipray, for example, is considered highly susceptible to climate change effects due to its rarity and high degree of habitat specialization ${ }^{47}$. For the Caspian Seal (Pusa caspica), warmer winters in the future might reduce the stability of ice breeding habitats and cause increased mortality among pups ${ }^{48}$. In addition, global warming is likely to have severe impacts on crocodilians and turtles with temperature-dependent sex determination, altering sex ratios and affecting population demographics ${ }^{49}$.

TABLE 1. Major threats to freshwater megafauna

\begin{tabular}{ll}
\hline Threats Impact & Examples \\
\hline
\end{tabular}




\begin{tabular}{|c|c|c|}
\hline $\begin{array}{l}\text { Overexploita- } \\
\text { tion }\end{array}$ & $\begin{array}{l}\text { Increased mortality due to intentional harvest or by- } \\
\text { catch; depletion or extirpation of local populations }\end{array}$ & $\begin{array}{l}\text { Arapaima gigas }{ }^{43,44}, \\
\text { Andrias davidianus } \\
\text { Crocodylus rhombifer } \\
52\end{array}$ \\
\hline $\begin{array}{l}\text { Dam } \\
\text { construction }\end{array}$ & $\begin{array}{l}\text { Blocked migration pathways for migratory species; } \\
\text { reduced access to spawning grounds; fragmented } \\
\text { population; altered natural flow and thermal regime, } \\
\text { thus influencing fitness and reproduction; drought and } \\
\text { habitat loss at downstream locations }\end{array}$ & $\begin{array}{l}\text { Acipenser gueldenstaedtii } \\
\text { Acipenser sinensis } \\
\text { Gavialis gangeticus }^{45} \\
\text { Kobus leche }^{54}\end{array}$ \\
\hline $\begin{array}{l}\text { Habitat } \\
\text { degradation }\end{array}$ & $\begin{array}{l}\text { Loss and fragmentation of required habitats and } \\
\text { spawning grounds; increased injury and death due to } \\
\text { conflict with humans (e.g. settlement, agriculture, } \\
\text { shipping) }\end{array}$ & $\begin{array}{l}\text { Crocodylus niloticus }^{55}, \\
\text { Hucho perryi } i^{56}, \\
\text { Pteronura brasiliensis }{ }^{57} \\
\text { Trichechus manatus }^{58}\end{array}$ \\
\hline Pollution & $\begin{array}{l}\text { Increased mortality due to acute toxicity and } \\
\text { bioaccumulation; degraded water quality (e.g. } \\
\text { eutrophication and sedimentation) resulting in } \\
\text { chemical barriers to fish movement and reduced } \\
\text { fitness; endocrine disruption leading to } \\
\text { developmental and reproductive abnormalities }\end{array}$ & $\begin{array}{l}\text { Crocodylus moreletii }^{59} \\
\text { Huso dauricus }^{60} \\
\text { Pusa sibirica }\end{array}$ \\
\hline $\begin{array}{l}\text { Species } \\
\text { invasion }\end{array}$ & $\begin{array}{l}\text { Competitive exclusion of native species; introduced } \\
\text { diseases; increased mortality through predation and } \\
\text { toxicity of venomous species; modified food web } \\
\text { structure; hybridization and introgression with native } \\
\text { species }\end{array}$ & $\begin{array}{l}\text { Acipenser nudiventris } \\
\text { Clarias macrocephalus }^{63}, \\
\text { Crocodylus johnstoni }^{64}, \\
\text { Hypselobarbus mussullah }^{65}, \\
\text { Tomistoma schlegelii }^{66}\end{array}$ \\
\hline $\begin{array}{l}\text { Climate } \\
\text { change }\end{array}$ & $\begin{array}{l}\text { Loss of suitable habitat due to changes in } \\
\text { temperature, precipitation patterns, and extreme } \\
\text { events (e.g. drought or flood); potential impact on } \\
\text { development and growth in reptiles }\end{array}$ & $\begin{array}{l}\text { Alligator sinensis }{ }^{67} \\
\text { Pusa caspica }\end{array}$ \\
\hline
\end{tabular}

Compared to other aquatic organisms, freshwater megafauna are typically more susceptible to hunting pressure and ecosystem degradation due to their long lifespan, large body size, late maturity and low fecundity ${ }^{68,69}$. They are exposed to a diverse array of threats before reaching maturity. Many freshwater megafauna species (e.g. the South American River Turtle, Podocnemis expansa, and the False Gharial, Tomistoma schlegelii) require at least ten years to reach sexual maturity ${ }^{66,70}$ while others (e.g. the Beluga, Huso huso and the Siamese Crocodile, Crocodylus siamensis) have generation times of 20 years or more ${ }^{32,71}$. Consequently, it may require many years to restore local populations to previous levels ${ }^{72}$. Unless actions are taken to change things, the current trajectory is for an increasing decline in the condition of freshwaters habitats, particularly in the species-rich Global South ${ }^{73-75}$.

\section{Overexploitation}

Overexploitation is a threat to many freshwater organisms, but it has often been accepted due to its long history throughout human civilization ${ }^{76}$. Harvesting in an unsustainable way has led to major adverse impacts on freshwater species worldwide ${ }^{77}$. Freshwater megafauna are particularly targeted as their meat, skin and eggs are often prized as high-value commodities, and they are often considered an "open access" free resource. For instance, sturgeons and paddlefishes have experienced a long history of intense overexploitation for caviar, pushing them to the brink of extinction $^{32}$. The global population of Siamese Crocodile has declined by more than $80 \%$ during the 
past 75 years due to hunting for its skin and the collection of eggs and living individuals ${ }^{71}$. The Critically Endangered Chinese Giant Salamander (Andrias davidianus), the world's largest amphibian, is experiencing an ongoing population decline because of the capture of wild individuals for their highly prized meat ${ }^{50,51}$.

Although many freshwater megafauna species are listed in the Convention on International Trade in Endangered Species of Wild Fauna and Flora (CITES), poaching remains a common phenomenon in many regions globally. For example, meat consumption has caused a sharp decline in the Cuban Crocodile (Crocodylus rhombifer), a species listed in CITES Appendix ${ }^{78}$. Relative to marine species, the capture of freshwater species is limited; however, it provides a critical source of animal protein for many local people, especially for poor communities in remote and rural areas ${ }^{79}, 80$. In Southeast Asia, which contributes more than a quarter of the total global inland capture fishery production $^{81}$, Giant Carp (Catlocarpio siamensis), Mekong Giant Salmon Carp (Aaptosyax grypus), Giant Pangasius (Pangasius sanitwongsei) and Mekong Giant Catfish (Pangasian odongigas) are on the brink of extinction, mainly due to overharvesting and the construction of dams (see section below).

Representing another form of exploitation, recreational fishing is a popular activity worldwide contributing approximately $12 \%$ of the global fish harvest ${ }^{82}$. Large freshwater fishes have been regarded as trophies since historical times, and popular use of terms such as "monster fish" and "river monsters" has increased the fascination for large freshwater fish" ${ }^{72}$. Recreational exploitation does of course add increasing pressure on freshwater megafauna and may have led to the decline of species such as Siberian Taimen (Hucho taimen) and Largetooth Sawfish (Pristis pristis ${ }^{83,84}$. On the other hand, popular media coverage on large fish and recreational fishing could help create an incentive and greater awareness to protect freshwater life ${ }^{85}$.

Given the intrinsic sparseness of freshwater megafauna and their declining population size, the opportunities for encountering mates for reproduction are more limited ${ }^{86}$. Moreover, the sparseness and/or rarity of these species can make them more attractive and valuable for exploitation and poaching ${ }^{87}$. It is also worth noting that the incidental capture as by-catch is a potentially significant threat for many freshwater megafauna species. For example, Turvey et al. ${ }^{36}$ suggested that unsustainable by-catch in local fisheries was the primary factor responsible for possible extinction of the Baiji. Similarly, the Yangtze Finless Porpoise (Neophocaena asiaeorientalis ssp. asiaeorientalis) is subject to incidental by-catch in gillnets ${ }^{88}$. In the Caspian Sea region, by-catch in legal and illegal fisheries may cause the death of several thousand Caspian Seals each year, representing a significant level of mortality for this threatened species in addition to intentional harvesting ${ }^{48}$.

\section{Dam construction}

For centuries, people have built dams along rivers for flood regulation, water supply, irrigation, navigation, recreation, and hydropower generation ${ }^{89}$. Driven by rapid human population growth and increasing energy demand, the number of dams has increased strongly during the past six decades ${ }^{90}$. Fragmentation and modified flow regime, both caused by dams, are among the most important anthropogenic impacts to the functioning of freshwater ecosystems ${ }^{91,}{ }^{92}$. For example, dams create physical obstructions to fish migration routes. Although various types of fish passages have been 
designed to improve connectivity along rivers, their efficiency often remains low, especially for species other than salmonids for which they were originally designed ${ }^{93}$.

Many freshwater megafauna species undertake long-distance migrations between breeding and feeding areas, therefore they are highly susceptible to blockage by dams. For example, during the past 60 years, the Russian Sturgeon (Acipenser gueldenstaedtii) has lost access to $70 \%$ of its spawning sites in the Caspian basin and to almost all spawning grounds in the Black Sea basin due to dam construction ${ }^{94}$. In addition, dams affect the thermal regime ${ }^{95}$ and may cause increased pollutants ${ }^{96}$, which could affect the growth and reproduction of freshwater megafauna. Angilletta et al. ${ }^{97}$ suggested that a modified thermal regime might have negative impacts on spawning activity and embryo development of Chinook Salmon. The spawning activity of the Chinese Sturgeon (Acipenser sinensis), for example, has been delayed and reduced by an increased water temperature downstream of the Three Gorges and the Gezhouba Dams (Yangtze River) ${ }^{53,98}$.

In addition to adverse impacts on fishes, dams have led to increased mortality levels and genetic isolation of African Manatee (Trichechus senegalensis) populations ${ }^{99}$. Most rivers inhabited by Gharial (Gavialis gangeticus) have been dammed for irrigation and other purposes. Subsequent seasonal droughts in previously perennial rivers may affect Gharial individuals that are not able to cross land in search of alternative water sources or dig tunnels to avoid periods of drought ${ }^{45}$. Dam construction and other river engineering projects (e.g. channel straightening, levee construction and dredging) may fundamentally affect floodplain inundation and lateral connectivity, leading to habitat loss of many freshwater megafauna species. For instance, droughts and altered flooding regimes due to damming have led to an estimated $50 \%$ decline in the population of Kafue Lechwe (Kobus leche ssp. kafuensis) on the Kafue Flats (Zambia) ${ }^{54}$.
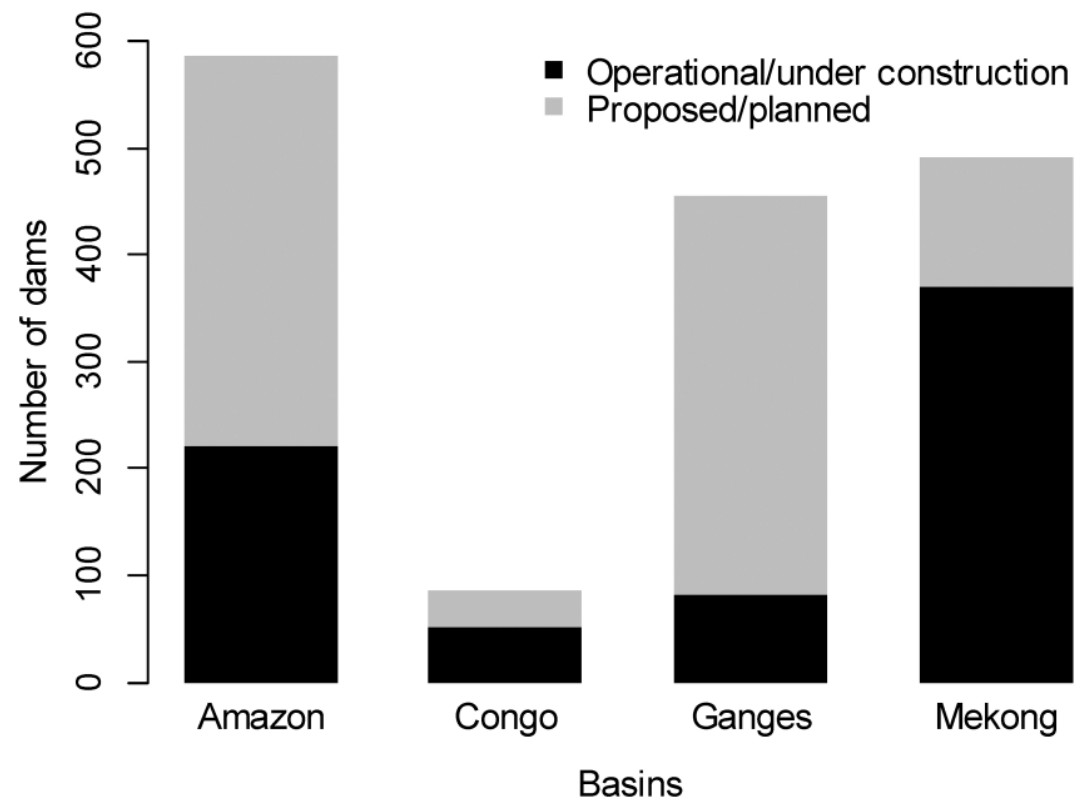

FIGURE 2. Numbers of hydropower dams in four selected megafauna-rich basins $s^{73,90,100}$. 
Many hydropower dams are planned or are under constructions in the Amazon, Mekong,

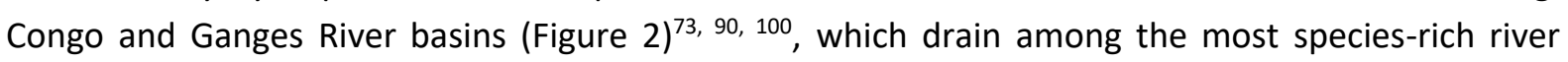
basins in the world. The boom in dam construction may threaten many freshwater megafauna species, including the Irrawaddy Dolphin (Orcaella brevirostris), Boto (Inia geoffrensis), Amazonian Manatee (Trichechus inunguis), Ganges River Dolphin (Platanista gangetica ssp. gangetica) and Giant Otter (Pteronura brasiliensis). It is also reported that already threatened tapirs (e.g. Baird's Tapir, Tapirus bairdii) were illegally hunted to feed construction workers during the construction of Chalillo Dam in Belize ${ }^{101}$, representing one of many additional impacts of dam construction including creation of infrastructure such as roads, and settlements and land-use change.

\section{A global boom in hydropower and its subsequent impacts}

Hydropower is a well-established technology for electricity production, accounting for about $80 \%$ of renewable energy production globally. Hydropower dam construction is currently accelerating worldwide, meeting increasing energy demands, in some case mitigating climate change consequences and closing the so-called electricity access gap. There are spatially explicit data available for 3700 hydropower dams (> $1 \mathrm{MW}$ ) worldwide that are either under construction or planned, which will more than double hydropower capacity within the next decades ${ }^{73}$. In addition to electricity production, hydropower dams may serve as flood control infrastructure, and their respective reservoirs provide recreational services, food through aquaculture, as well as water for irrigation and industrial/domestic supply. However, hydropower development can also have severe social, economic and ecological consequences. Depending on the location and size of a reservoir, human populations may have to be relocated. Transboundary conflicts may arise from alterations in water availability downstream of dams. Land use change, river fragmentation, and alteration of flow, sediment and thermal regimes cause habitat loss, restrict the movement of aquatic organisms, and alter biodiversity and ecosystem processes ${ }^{100}$. However, knowledge on the expected social, economic, and ecological ramifications is limited and remains under-valued by practitioners. There is an urgent need to integrate the economic, environmental and social dimensions of future hydropower dams, thereby supporting decision making for dam construction and subsequent operation aims to reduce potential impacts and maximize benefits for both, humans and nature alike. Finally, we must be aware that the majority of dams are constructed for irrigation, drinking water and flood control - not for hydropower production; however, comprehensive data on those dams are missing.

\section{Habitat degradation}

Habitat degradation in freshwater ecosystems is caused by diverse human activities, creating direct (e.g. disturbance due to sand extraction and river straightening) and indirect impacts posed by environmental changes within the catchment (e.g. subsequent influence of deforestation and agricultural activities) $)^{77}$. For example, sand and pebble extraction along the Manipur River (Myanmar/India) has led to a rapid decline in populations of Hemibagrus microphthalmus ${ }^{102}$. Similarly, gold mining as well as sand and gravel extraction from river beds in Mongolia, have caused serious degradation of Siberian Taimen habitats, leading to the decline of mature individuals ${ }^{103}$. 
The dependence of freshwater megafauna on freshwater habitats imparts on them a high chance of encountering human settlements and activities, aggravated by their large range requirements of intact and hydrologically connected habitats ${ }^{104}$, increasing their susceptibility to anthropogenic disturbance. The global increase of shipping activities represents a serious threat to sturgeons, freshwater cetaceans and manatees due to their frequent encounters with vessels. Indeed, collisions with shipping vessels have increased substantially, causing the death of many Yangtze Finless Porpoise ${ }^{105}$ and approximately $30 \%$ of documented Florida Manatee (Trichechus manatus ssp. latirostris) mortalities each year ${ }^{58}$.

In South America, Giant Otter populations have declined sharply following expansion of human settlements, habitat degradation due to gold mining and deforestation, and hunting ${ }^{57}$. Many crocodilians, including Mugger (Crocodylus palustris), Slender-snouted Crocodile (Mecistops cataphractus) and Nile Crocodile (Crocodylus niloticus), are threatened by habitat destruction caused by anthropogenic activities. In addition, they are regularly killed by local people as they are regarded as a threat to humans and domestic livestock ${ }^{106,}{ }^{107}$. With rapid human population growth, urbanization, agricultural and industrial expansion, there is an increasing likelihood of conflict due to encroachment by humans into the natural habitats of freshwater megafauna ${ }^{108}$. In Africa, for example, the historical habitats of African Clawless Otter (Aonyx capensis) have been significantly degraded by deforestation, bush clearing, overgrazing, water abstraction and the draining of wetlands ${ }^{109}$. The Pygmy Hippopotamus (Choeropsis liberiensis ssp. liberiensis), which is endemic to the Upper Guinea forest of west Africa, is seriously threatened by habitat destruction as its historical forest habitat has been cut for the creation of human settlements, farms and plantations ${ }^{110,111}$. Increasing mining activities and associated infrastructure development will put further stress on this threatened species ${ }^{112}$. Similarly, the Sakhalin Taimen (Hucho perryi) has suffered from major habitat changes in Russia due to logging, road construction and rapidly expanding oil and gas developments, while its habitats in Japan are under threat from river channelization, agricultural and urban expansion ${ }^{56}$.

\section{Pollution}

A wide range of chemical compounds are applied globally for purposes such as pest control and fertilizers in agriculture, industrial manufacturing, and as everyday products ranging from detergents to antibiotics. A substantial proportion of these pollutants ends up in freshwater ecosystems through diverse pathways including direct discharge, surface runoff and atmospheric deposition ${ }^{113}$. The toxic effects of some chemical pollutants can cause mortality in freshwater megafauna species such as the death of an estimated 4000 Caspian Seals along the coast of Kazakhstan due to pollution from agricultural and industrial sewage ${ }^{114}$. Other notable examples include the mortality of five Yangtze Finless Porpoises in the Dongting Lake (China) within a single week due to the toxic effect of a pesticide (i.e. Hostathion) and, possibly, long-term exposure to heavy metals (e.g. mercury and chromium $)^{115}$. This represents a significant loss as the current population in the Dongting Lake is only around 90 individuals with an estimated 500 more individuals living in the main channel of the Yangtze River ${ }^{116}$.

Compared to most aquatic organisms, freshwater megafauna species are at higher risk of chronic effects and bioaccumulation of chemicals due to their long life span and high trophic level. 
Both, the Amur Sturgeon (Acipenser schrenckii) and the Kaluga Sturgeon (Huso dauricus) are exposed to the cumulative effects of environmental pollution from oil exploitation, agricultural activities and mining operations in the Amur River basin ${ }^{60,117}$. Though pollutants might not be directly lethal to freshwater megafauna, they may reduce fitness and fecundity and make them more susceptible to disease. As a top predator in Lake Baikal, the Baikal Seal (Pusa sibirica) is exposed to bioaccumulation of contaminants (e.g. polychlorinated biphenyls), which induce a suppression of its immune system and may have contributed to an outbreak of morbillivirus, which indirectly led to a mass mortality event in the late $1980 \mathrm{~s}^{61}$.

On the global scale, toxicants released by human activities have been identified as a major threat to freshwater ecosystems by The Millennium Ecosystem Assessment ${ }^{118}$. Organic pollutants and heavy metals have been considered as the greatest threat to freshwater organisms. These pollutants enter freshwaters through waste water treatment plants, industrial discharge, mining drainage and runoff from agricultural soils and urban surfaces ${ }^{119}$. They have been found in fine sediments ${ }^{120}$, causing extirpation of the benthic fauna ${ }^{121}$, which is an important food resource for some freshwater megafauna species (e.g. sturgeons). Pollutants carried by sediments can also lead to an increased mortality of sturgeons due to their direct toxic effects ${ }^{122}$. In North America, elevated concentrations of organic pollutants and heavy metals have been detected in the tissue and egg samples of Gulf Sturgeon (Acipenser oxyrinchus) ${ }^{123}$. An increasing amount of research has reported that organic pollutants (e.g. organochlorine) and heavy metals from pesticide and industrial waste were detected in tissue and eggs of numerous crocodilians, including American Alligator ${ }^{124}$, Saltwater Crocodile (Crocodylus porosus) ${ }^{125}$, American Crocodile (Crocodylus acutus) ${ }^{126}$, Morelet's Crocodile (Crocodylus moreletii) ${ }^{59}$ and Nile Crocodile ${ }^{127}$, which could lead to further population declines of these already threatened species. In addition, endocrine disrupting organic pollutants are reported to alter the hormonal balance of aquatic animals, inducing developmental and reproductive abnormalities ${ }^{128-130}$ and ultimately leading to a population decline. For example, estrogenic pollution from industrial, agricultural and waste water treatment plant effluents contributed to the occurrence of intersex Sharptooth Catfish (Clarias gariepinus) individuals in South Africa $^{131,132}$.

\section{Species invasion}

The introduction of non-indigenous species often produces predatory or competitive impacts on native species, therefore influencing local animal assemblages and ecosystem processes ${ }^{133}$. Species invasion is regarded as a major threat to global biodiversity, although its relative contribution to species decline and extinction is debatable as native species and their habitats are usually also subject to various other anthropogenic threats simultaneously ${ }^{134,135}$. Due to their large body size, adult freshwater megafauna individuals are not likely to become the prey of invasive species, however, they are at risk during hatching and juvenile periods. Bezuijen et al. ${ }^{66}$ showed that introduction of the Wild Pig (Sus scrofa) posed a serious stress to the False Gharial in Sumatra due to predation of eggs. Invasive species can directly increase the mortality of native freshwater megafauna populations. For example, the invasion of Cane Toads (Bufo marinus) has led to the massive mortality of Australian Freshwater Crocodiles (Crocodylus johnstoni) as they consume the toads which contain powerful toxins in their parotid glands ${ }^{64}$. Less directly, Lake Trout (Salvelinus namaycush) populations in Ontario lakes declined following introductions of Smallmouth Bass 
(Micropterus dolomieu) and Rock Bass (Ambloplites rupestris) that led to a decline in their key food source, native littoral prey fishes through competition ${ }^{136}$. Introduced Comb Jellyfish (Mnemiopsis leidyi) posed a serious risk to Kilka (Clupeonella cultriventris), the main prey of Caspian Seal in the central and the southern Caspian Sea, by depleting Kilka's food base (e.g. zooplankton) and also through predation on their eggs and larvae ${ }^{137,138}$. In most cases, invasive species affect freshwater megafauna through competition for resources or through induced profound changes to local food webs, however, hybridization with invasive species is also a significant threat. For example, the hybrid of Broadhead Catfish (Clarias macrocephalus) and the introduced African Catfish (Clarias gariepinus) is capable of breeding with both species, which can result in genetic introgression, thus leading to the local extinction of native Broadhead Catfish ${ }^{63}$. In addition, the hybrids grow faster than the native Broadhead Catfish and are highly tolerant towards degraded water quality, giving them a competitive advantage ${ }^{139}$.

In the last few decades, managed relocation, of species to areas outside of the native ranges has become a common practice for reducing their risk of extinction ${ }^{140}$; however, it can also lead to unintended negative effects. For instance, the Hump Backed Mahseer (Hypselobarbus mussullah), an endemic species in the Western Ghats of India, has been pushed to the edge of extinction due to the successful establishment and spread of the non-native Blue-finned Mahseer (Tor khudree), which was introduced for conservation purposes ${ }^{65}$. Likewise, the invasive monogenean gill fluke, carried by Stellate Sturgeon (Acipenser stellatus) and was inadvertently introduced from the Caspian Sea and played a significant role in the extirpation of Ship Sturgeon (Acipenser nudiventris) in the Aral Sea ${ }^{62}$

\section{OUTLOOK: FILLING THE FRESHWATER MEGAFAUNA INFORMATION GAP}

Freshwater megafauna, but also freshwater ecosystems in general, are globally at risk from overexploitation, dam construction, habitat degradation, pollution and species invasion. At the same time, freshwaters contain a disproportionately high biodiversity and provide vital goods and services to humans. Conversely, freshwater ecosystems are underrepresented in conservation research and management actions ${ }^{76,141-143}$.

Though there is a general consensus that freshwater biodiversity is declining rapidly, the effective coverage of freshwaters by protected areas remains low, especially for large rivers ${ }^{144}$. The lack of public awareness towards biodiversity in freshwaters could largely stem from the invisibility of freshwater species hidden in turbid waters ${ }^{145}$. Subsequently this may lead to a shift in the baselines, where many people forget the previous existence and abundance of such species as they are rarely encountered, further impeding awareness and knowledge of these species ${ }^{8}$. Highlighting freshwater megafauna is potential flagship and umbrella species is recommended here as a potentially powerful tool to help raise public awareness and support freshwater conservation. Freshwater megafauna species such as river dolphins, hippopotamuses, sturgeons and paddlefishes are considered to have significant potential as both flagship and umbrella species ${ }^{146}$ (Table 2). Furthermore, conservation strategies based on freshwater megafauna may provide major benefits for a wide range of lesser known but cohabiting species as well as of key ecosystems processes and functions. Darwall et al. ${ }^{147}$ cautioned, however, that those taxonomic groups for which there is better knowledge (most often terrestrial species) should not be utilized as surrogates for the 
distributions of less known freshwater taxa where it has been shown that there is low congruence between terrestrial and freshwater species distributions. Research focusing on charismatic species in freshwaters could improve their surrogacy effectiveness (i.e. benefit a larger set of less charismatic species via their umbrella effects) ${ }^{148}$.

TABLE 2. Focal species concepts $7,149,150$, with examples from freshwater megafauna

\begin{tabular}{lll}
\hline Type & Description & Examples \\
\hline Flagship & $\begin{array}{l}\text { Charismatic species that could act as ambassadors for } \\
\text { broad-scale conservation, used to raise conservation } \\
\text { funding, and to attract public attention. } \\
\text { Keystone }\end{array}$ & $\begin{array}{l}\text { River dolphins, giant } \\
\text { salamanders, hippopotamus, } \\
\text { sturgeons and paddlefishes } \\
\text { local ecosystems, and have disproportionate } \\
\text { importance relative to their abundance. }\end{array}$ \\
$\begin{array}{l}\text { Umbrella } \\
\text { Species with large habitat requirements for which } \\
\text { conservation action potentially benefits other } \\
\text { sympatric species. }\end{array}$ & $\begin{array}{l}\text { Beavers, crocodilians, } \\
\text { Hippopotamus }\end{array}$ \\
$\begin{array}{l}\text { River dolphins, } \\
\text { hippopotamus, sturgeons } \\
\text { and paddlefishes }\end{array}$ \\
\hline
\end{tabular}

To conclude, our knowledge of large-scale distribution and risk patterns of freshwater megafauna is still lacking for large parts of the world. Future research should focus on these large animals in order to fill knowledge gap by: (i) collating information on their spatial distributions; (ii) exploring the potential of freshwater megafauna to act as flagship and umbrella species; (iii) compiling data to quantify the seriousness of each type of threat and their impacts to each taxonomic group; (iv) identifying potential regions of conflict between the requirements of freshwater megafauna biodiversity and human activities; $(v)$ examining correlations between biological and ecological traits of freshwater megafauna and extinction risk; and (vi) tracking the global population dynamics of freshwater megafauna. Such a comprehensive understanding of freshwater megafauna will assist in the development of more effective conservation strategies and better consideration within development planning, in order to protect these species and to raise public awareness and support for overall freshwater biodiversity conservation.

\section{ACKNOWLEDGMENTS}

This work has been carried out within the SMART Joint Doctorate Programme (Science for the MAnagement of Rivers and their Tidal systems) funded with the support of the Erasmus Mundus programme of the European Union. SCJ acknowledges funding by the German Federal Ministry of Education and Research (BMBF) for funding "GLANCE" (Global change effects in river ecosystems; 01LN1320A). We are grateful to Huijuan Li for supporting the design of the graphic abstract. We thank two anonymous referees and the associated editor Gemma Harvey for their constructive comments on the manuscript.

\section{REFERENCES}

1. Barnosky AD, Koch PL, Feranec RS, Wing SL, Shabel AB. Assessing the causes of Late Pleistocene extinctions on the continents. Science 2004, 306:70-75.

2. Martin PS, Klein RG. Quaternary extinctions: a prehistoric revolution: University of Arizona Press; 1989. 
3. Durant SM, Wacher T, Bashir S, Woodroffe R, De Ornellas P, Ransom C, Newby J, Abaigar T, Abdelgadir $\mathrm{M}$, El Alqamy $\mathrm{H}$, et al. Fiddling in biodiversity hotspots while deserts burn? Collapse of the Sahara's megafauna. Diversity and Distributions 2014, 20:114-122.

4. Hansen DM, Galetti M. The Forgotten Megafauna. Science 2009, 324:42-43.

5. Ripple WJ, Chapron G, López-Bao JV, Durant SM, Macdonald DW, Lindsey PA, Bennett EL, Beschta RL, Bruskotter JT, Campos-Arceiz A, et al. Saving the World's Terrestrial Megafauna. BioScience 2016:doi: 10.1093/biosci/biw1092.

6. Donlan J, Berger J, Bock CE, Bock JH, Burney DA, Estes JA, Foreman D, Martin PS, Roemer GW, Smith FA, et al. Re-wilding North America. Nature 2005, 436:913-914.

7. Hooker SK, Gerber LR. Marine reserves as a tool for ecosystem-based management: The potential importance of megafauna. Bioscience 2004, 54:27-39.

8. Turvey ST, Barrett LA, Hao YJ, Zhang L, Zhang XQ, Wang XY, Huang YD, Zhou KY, Hart T, Wang D. Rapidly Shifting Baselines in Yangtze Fishing Communities and Local Memory of Extinct Species. Conservation Biology 2010, 24:778-787.

9. Turvey ST, Risley CL, Barrett LA, Hao YJ, Ding W. River Dolphins Can Act as Population Trend Indicators in Degraded Freshwater Systems. Plos One 2012, 7: e37902.

10. Cardillo M, Mace GM, Jones KE, Bielby J, Bininda-Emonds ORP, Sechrest W, Orme CDL, Purvis A. Multiple causes of high extinction risk in large mammal species. Science 2005, 309:12391241.

11. Sergio F, Newton I, Marchesi L, Pedrini P. Ecologically justified charisma: preservation of top predators delivers biodiversity conservation. Journal of Applied Ecology 2006, 43:1049-1055.

12. Leader-Williams N, Dublin HT. Charismatic megafauna as 'flagship species'. In: Priorities for the conservation of mammalian diversity: has the panda had its day. Cambridge: Cambridge University Press; 2000, 53-81.

13. Walpole MJ, Leader-Williams N. Tourism and flagship species in conservation. Biodiversity and Conservation 2002, 11:543-547.

14. Sergio F, Caro T, Brown D, Clucas B, Hunter J, Ketchum J, McHugh K, Hiraldo F. Top Predators as Conservation Tools: Ecological Rationale, Assumptions, and Efficacy. Annual Review of Ecology Evolution and Systematics 2008, 39:1-19.

15. Caro T, Riggio J. Conservation and behavior of Africa's "Big Five". Current Zoology 2014, 60:486-499.

16. Cooke SJ, Lapointe NWR, Martins EG, Thiem JD, Raby GD, Taylor MK, Beard TD, Cowx IG. Failure to engage the public in issues related to inland fishes and fisheries: strategies for building public and political will to promote meaningful conservation. Journal of Fish Biology 2013, 83:997-1018.

17. Jenkins M. Prospects for biodiversity. Science 2003, 302:1175-1177.

18. WWF. Living Planet Report 2016. Risk and resilience in a new era. Gland, Switzerland: WWF International; 2016.

19. Sala OE, Chapin FS, Armesto JJ, Berlow E, Bloomfield J, Dirzo R, Huber-Sanwald E, Huenneke LF, Jackson RB, Kinzig A, et al. Biodiversity - Global biodiversity scenarios for the year 2100 . Science 2000, 287:1770-1774.

20. Moore JW. Animal ecosystem engineers in streams. Bioscience 2006, 56:237-246.

21. McCarthy TS, Ellery WN, Bloem A. Some observations on the geomorphological impact of hippopotamus (Hippopotamus amphibius L.) in the Okavango Delta, Botswana. African Journal of Ecology 1998, 36:44-56.

22. Mosepele K, Moyle PB, Merron GS, Purkey DR, Mosepele B. Fish, Floods, and Ecosystem Engineers: Aquatic Conservation in the Okavango Delta, Botswana. Bioscience 2009, 59:5364.

23. Wright JP, Jones CG, Flecker AS. An ecosystem engineer, the beaver, increases species richness at the landscape scale. Oecologia 2002, 132:96-101. 
24. Nummi P, Holopainen S. Whole-community facilitation by beaver: ecosystem engineer increases waterbird diversity. Aquatic Conservation-Marine and Freshwater Ecosystems 2014, 24:623-633.

25. Wohl E. Of wood and rivers: bridging the perception gap. Wiley Interdisciplinary ReviewsWater 2015, 2:167-176.

26. Campbell MR, Mazzotti FJ. Characterization of natural and artificial alligator holes. Southeastern Naturalist 2004, 3:583-594.

27. Doughty CE, Roman J, Faurby S, Wolf A, Haque A, Bakker ES, Malhi Y, Dunning JB, Svenning JC. Global nutrient transport in a world of giants. Proceedings of the National Academy of Sciences of the United States of America 2016, 113:868-873.

28. Gende SM, Edwards RT, Willson MF, Wipfli MS. Pacific salmon in aquatic and terrestrial ecosystems. Bioscience 2002, 52:917-928.

29. Estes JA, Terborgh J, Brashares JS, Power ME, Berger J, Bond WJ, Carpenter SR, Essington TE, Holt RD, Jackson JBC, et al. Trophic Downgrading of Planet Earth. Science 2011, 333:301-306.

30. Osterling EM, Soderberg H. Sea-trout habitat fragmentation affects threatened freshwater pearl mussel. Biological Conservation 2015, 186:197-203.

31. Huang SL, Hao YJ, Mei ZG, Turvey ST, Wang D. Common pattern of population decline for freshwater cetacean species in deteriorating habitats. Freshwater Biology 2012, 57:12661276.

32. Pikitch EK, Doukakis P, Lauck L, Chakrabarty P, Erickson DL. Status, trends and management of sturgeon and paddlefish fisheries. Fish and Fisheries 2005, 6:233-265.

33. Gessner J, Jaric I, Rochard E, Pourkazemi M. Sturgeon and paddlefish research focuses on low risk species and largely disregards endangered species. Endangered Species Research 2013, 22:95-97.

34. IUCN. The IUCN Red List of Threatened Species. Version 2016-1. 2016. Available at: http://www.iucnredlist.org. Access date: 02 August 2016.

35. Zhang H, Balk H, Wang C, Wu J, Du H, Shen L, Liu Z, Wei Q. Search for Chinese paddlefish (Psephurus gladius) in the upper Yangtze River during 2009-2013 including reevaluation of data from 2006 to 2008. Aquatic Living Resources 2016, 29:101.

36. Turvey ST, Pitman RL, Taylor BL, Barlow J, Akamatsu T, Barrett LA, Zhao XJ, Reeves RR, Stewart BS, Wang KX, et al. First human-caused extinction of a cetacean species? Biology Letters 2007, 3:537-540.

37. Bronzi P, Congiu L, Rossi R, Zerunian S, Arlati G. Acipenser naccarii. The IUCN Red List of Threatened Species 2013: e.T224A13037056. 2013.

38. Wu JM, Wei QW, Du H, Wang CY, Zhang H. Initial evaluation of the release programme for Dabry's sturgeon (Acipenser dabryanus Dumeril, 1868) in the upper Yangtze River. Journal of Applied Ichthyology 2014, 30:1423-1427.

39. Williot $P$, Rochard $E$, Rouault $T$, Kirschbaum $F$. Acipenser sturio recovery research actions in France. In: Biology, conservation and sustainable development of sturgeons. Amsterdam: Springer; 2009, 247-263.

40. Last PR, Manjaji-Matsumoto BM. Himantura dalyensis sp. nov., a new estuarine whipray (Myliobatoidei: Dasyatidae) from northern Australia. Descriptions of New Australian Chondrichthyans 2008:283-291.

41. Stewart DJ. A New Species of Arapaima (Osteoglossomorpha: Osteoglossidae) from the Solimoes River, Amazonas State, Brazil. Copeia 2013:470-476.

42. Stewart DJ. Re-description of Arapaima agassizii (Valenciennes), a rare fish from Brazil (Osteoglossomorpha: Osteoglossidae). Copeia 2013:38-51.

43. Castello L, McGrath DG, Hess LL, Coe MT, Lefebvre PA, Petry P, Macedo MN, Reno VF, Arantes CC. The vulnerability of Amazon freshwater ecosystems. Conservation Letters 2013, 6:217-229. 
44. Cavole LM, Arantes CC, Castello L. How illegal are tropical small-scale fisheries? An estimate for arapaima in the Amazon. Fisheries Research 2015, 168:1-5.

45. Choudhury BC, Singh LAK, Rao RJ, Basu D, Sharma RK, Hussain SA, Andrews HV, Whitaker N, Whitaker R, Lenin J, et al. Gavialis gangeticus. The IUCN Red List of Threatened Species 2007: e.T8966A12939997. 2007.

46. Gesner J, Freyhof J, Kottelat M. Acipenser gueldenstaedtii. The IUCN Red List of Threatened Species 2010: e.T232A13042340. 2010.

47. Chin A, Kyne PM, Walker TI, Mcauley RB. An integrated risk assessment for climate change: analysing the vulnerability of sharks and rays on Australia's Great Barrier Reef. Global Change Biology 2010, 16:1936-1953.

48. Härkönen T. Pusa caspica. The IUCN Red List of Threatened Species 2008: e.T41669A10532115. 2008.

49. Gibbons JW, Scott DE, Ryan TJ, Buhlmann KA, Tuberville TD, Metts BS, Greene JL, Mills T, Leiden Y, Poppy S, et al. The global decline of reptiles, Deja Vu amphibians. Bioscience 2000, 50:653-666.

50. Tapley B, Okada S, Redbond J, Turvey ST, Chen S, Lu JC, Wei G, Wu MY, Pan Y, Niu KF, et al. Failure to detect the Chinese giant salamander (Andrias davidianus) in Fanjingshan National Nature Reserve, Guizhou Province, China. Salamandra 2015, 51:206-208.

51. Xie F, Lau MWN, Stuart SN, Chanson JS, Cox NA, Fischman DL. Conservation needs of amphibians in China: A review. Science in China Series C-Life Sciences 2007, 50:265-276.

52. Targarona RR, Soberón RR, Tabet MA, Thorbjarnarson JB, Manolis S, Stevenson C. Cuban crocodile (Crocodylus rhombifer). Crocodiles: status, survey and conservation action plan. Third edition. Darwin: Crocodile Specialist Group 2010:114-118.

53. Wu JM, Wang CY, Zhang H, Du H, Liu ZG, Shen L, Wei QW, Rosenthal H. Drastic decline in spawning activity of Chinese sturgeon Acipenser sinensis Gray 1835 in the remaining spawning ground of the Yangtze River since the construction of hydrodams. Journal of Applied Ichthyology 2015, 31:839-842.

54. IUCN SSC Antelope Specialist Group. Kobus leche. The IUCN Red List of Threatened Species 2008: e.T11033A3241464. 2008.

55. Ashton PJ. The demise of the Nile crocodile (Crocodylus niloticus) as a keystone species for aquatic ecosystem conservation in South Africa: The case of the Olifants River. Aquatic Conservation-Marine and Freshwater Ecosystems 2010, 20:489-493.

56. Rand PS. Hucho perryi. The IUCN Red List of Threatened Species 2006: e.T61333A12462795. 2006.

57. Groenendijk J, Duplaix N, Marmontel M, Van Damme P, Schenck C. Pteronura brasiliensis. The IUCN Red List of Threatened Species 2015: e.T18711A21938411. 2015.

58. Nowacek SM, Wells RS, Owen ECG, Speakman TR, Flamm RO, Nowacek DP. Florida manatees, Trichechus manatus latirostris, respond to approaching vessels. Biological Conservation 2004, 119:517-523.

59. Rainwater TR, Wu TH, Finger AG, Canas JE, Yu L, Reynolds KD, Coimbatore G, Barr B, Platt SG, Cobb GP, et al. Metals and organochlorine pesticides in caudal scutes of crocodiles from Belize and Costa Rica. Science of the Total Environment 2007, 373:146-156.

60. Shmigirilov AP, Mednikova AA, Israel JA. Comparison of biology of the Sakhalin sturgeon, Amur sturgeon, and kaluga from the Amur River, Sea of Okhotsk, and Sea of Japan biogeographic Province. Environmental Biology of Fishes 2007, 79:383-395.

61. Tsydenova O, Minh TB, Kajiwara N, Batoev V, Tanabe S. Recent contamination by persistent organochlorines in Baikal seal (Phoca sibirica) from Lake Baikal, Russia. Marine Pollution Bulletin 2004, 48:749-758.

62. Strauss A, White A, Boots M. Invading with biological weapons: the importance of diseasemediated invasions. Functional Ecology 2012, 26:1249-1261. 
63. Na-Nakorn U, Kamonrat W, Ngamsiri T. Genetic diversity of walking catfish, Clarias macrocephalus, in Thailand and evidence of genetic introgression from introduced farmed Cgariepinus. Aquaculture 2004, 240:145-163.

64. Letnic M, Webb JK, Shine R. Invasive cane toads (Bufo marinus) cause mass mortality of freshwater crocodiles (Crocodylus johnstoni) in tropical Australia. Biological Conservation 2008, 141:1773-1782.

65. Pinder AC, Raghavan R, Britton JR. The legendary hump-backed mahseer Tor sp of India's River Cauvery: an endemic fish swimming towards extinction? Endangered Species Research 2015, 28:11-17.

66. Bezuijen MR, Shwedick B, Simpson BK, Staniewicz A, Stuebing R. Tomistoma schlegelii. The IUCN Red List of Threatened Species 2014: e.T21981A2780499. 2014.

67. Zhang F, Li Y, Guo Z, Murray BR. Climate warming and reproduction in Chinese alligators. Animal Conservation 2009, 12:128-137.

68. Olden JD, Hogan ZS, Vander Zanden MJ. Small fish, big fish, red fish, blue fish: size-biased extinction risk of the world's freshwater and marine fishes. Global Ecology and Biogeography 2007, 16:694-701.

69. Geist J. Integrative freshwater ecology and biodiversity conservation. Ecological Indicators 2011, 11:1507-1516.

70. Mogollones SC, Rodriguez DJ, Hernandez O, Barreto GR. A Demographic Study of the Arrau Turtle (Podocnemis expansa) in the Middle Orinoco River, Venezuela. Chelonian Conservation and Biology 2010, 9:79-89.

71. Bezuijen M, Simpson B, Behler N, Daltry J, Tempsiripong Y. Crocodylus siamensis. The IUCN Red List of Threatened Species 2012: e.T5671A3048087. 2012.

72. Winemiller KO, Humphries P, Pusey BJ. Protecting large apex predators. In: Closs GP, Krkosek $\mathrm{M}$, Olden JD, eds. Conservation of Freshwater Fishes. Cambridge, UK: Cambridge University Press; 2015, 361-398.

73. Zarfl C, Lumsdon AE, Berlekamp J, Tydecks L, Tockner K. A global boom in hydropower dam construction. Aquatic Sciences 2015, 77:161-170.

74. Bunn SE. Grand challenge for the future of freshwater ecosystems. Frontiers in Environmental Science 2016, 4:21.

75. Vorosmarty CJ, Pahl-Wostl C, Bunn SE, Lawford R. Global water, the anthropocene and the transformation of a science. Current Opinion in Environmental Sustainability 2013, 5:539550.

76. Abell R. Conservation biology for the biodiversity crisis: A freshwater follow-up. Conservation Biology 2002, 16:1435-1437.

77. Dudgeon D, Arthington AH, Gessner MO, Kawabata ZI, Knowler DJ, Leveque C, Naiman RJ, Prieur-Richard AH, Soto D, Stiassny ML, et al. Freshwater biodiversity: importance, threats, status and conservation challenges. Biological Reviews 2006, 81:163-182.

78. Ramos Targarona R, Soberón RR, Tabet MA, Thorbjarnarson JB, Manolis S, Stevenson C. Cuban crocodile (Crocodylus rhombifer). Crocodiles: status, survey and conservation action plan. Third edition. Darwin: Crocodile Specialist Group 2010:114-118.

79. Allan JD, Abell R, Hogan Z, Revenga C, Taylor BW, Welcomme RL, Winemiller K. Overfishing of inland waters. Bioscience 2005, 55:1041-1051.

80. Welcomme RL, Cowx IG, Coates D, Bene C, Funge-Smith S, Halls A, Lorenzen K. Inland capture fisheries. Philosophical Transactions of the Royal Society B-Biological Sciences 2010, 365:2881-2896.

81. Welcomme RL, Baird IG, Dudgeon D, Halls A, Lamberts D, Mustafa MG. Fisheries of the rivers of Southeast Asia. Freshwater Fisheries Ecology 2015:363-376.

82. Cooke SJ, Cowx IG. The role of recreational fishing in global fish crises. Bioscience 2004, 54:857-859. 
83. Fernandez-Carvalho J, Imhoff JL, Faria VV, Carlson JK, Burgess GH. Status and the potential for extinction of the largetooth sawfish Pristis pristis in the Atlantic Ocean. Aquatic Conservation-Marine and Freshwater Ecosystems 2014, 24:478-497.

84. Jensen OP, Gilroy DJ, Hogan Z, Allen BC, Hrabik TR, Weidel BC, Chandra S, Vander Zanden MJ. Evaluating recreational fisheries for an endangered species: a case study of taimen, Hucho taimen, in Mongolia. Canadian Journal of Fisheries and Aquatic Sciences 2009, 66:1707-1718.

85. Granek EF, Madin EMP, Brown MA, Figueira W, Cameron DS, Hogan Z, Kristianson G, De Villiers $\mathrm{P}$, Williaims JE, Post J, et al. Engaging Recreational Fishers in Management and Conservation: Global Case Studies. Conservation Biology 2008, 22:1125-1134.

86. Bronzi P, Rosenthal H, Gessner J. Global sturgeon aquaculture production: an overview. Journal of Applied Ichthyology 2011, 27:169-175.

87. Courchamp F, Angulo E, Rivalan P, Hall RJ, Signoret L, Bull L, Meinard Y. Rarity value and species extinction: The anthropogenic Allee effect. Plos Biology 2006, 4:2405-2410.

88. Zhao XJ, Barlow J, Taylor BL, Pitman RL, Wang KX, Wei Z, Stewart BS, Turvey ST, Akamatsu T, Reeves RR, et al. Abundance and conservation status of the Yangtze finless porpoise in the Yangtze River, China. Biological Conservation 2008, 141:3006-3018.

89. World Commission on Dams. Dams and Development: A New Framework for Decisionmaking: the Report of the World Commission on Dams. London: Earthscan; 2000.

90. Lehner B, Liermann CR, Revenga C, Vorosmarty C, Fekete B, Crouzet P, Doll P, Endejan M, Frenken $\mathrm{K}$, Magome J, et al. High-resolution mapping of the world's reservoirs and dams for sustainable river-flow management. Frontiers in Ecology and the Environment 2011, 9:494502.

91. Fan XG, Wei QW, Chang JB, Rosenthal H, He JX, Chen DQ, Shen L, Du H, Yang DG. A review on conservation issues in the upper Yangtze River - a last chance for a big challenge: Can Chinese paddlefish (Psephurus gladius), Dabrys sturgeon, (Acipenser dabryanus) and other fish species still be saved? Journal of Applied Ichthyology 2006, 22:32-39.

92. Poff NL, Hart DD. How dams vary and why it matters for the emerging science of dam removal. Bioscience 2002, 52:659-668.

93. Noonan MJ, Grant JWA, Jackson CD. A quantitative assessment of fish passage efficiency. Fish and Fisheries 2012, 13:450-464.

94. Gessner J, Freyhof J, Kottelat M. Acipenser gueldenstaedtii. The IUCN Red List of Threatened Species 2010: e.T232A13042340. 2010.

95. Olden JD. Challenges and opportunities for fish conservation in dam-impacted waters. In: P. CG, M. K, D. OJ, eds. Conservation of Freshwater Fishes. Cambridge, UK: Cambridge University Press; 2015, 107-148.

96. Feist GW, Webb MAH, Gundersen DT, Foster EP, Schreck CB, Maule AG, Fitzpatrick MS. Evidence of detrimental effects of environmental contaminants on growth and reproductive physiology of white sturgeon in impounded areas of the Columbia River. Environmental Health Perspectives 2005, 113:1675-1682.

97. Angilletta MJ, Steel EA, Bartz KK, Kingsolver JG, Scheuerell MD, Beckman BR, Crozier LG. Big dams and salmon evolution: changes in thermal regimes and their potential evolutionary consequences. Evolutionary Applications 2008, 1:286-299.

98. Zhuang P, Zhao F, Zhang T, Chen Y, Liu JY, Zhang LZ, Kynard B. New evidence may support the persistence and adaptability of the near-extinct Chinese sturgeon. Biological Conservation 2016, 193:66-69.

99. Keith Diagne L. Trichechus senegalensis. The IUCN Red List of Threatened Species 2015: e.T22104A81904980. 2015. 
100. Winemiller KO, McIntyre PB, Castello L, Fluet-Chouinard E, Giarrizzo T, Nam S, Baird IG, Darwall W, Lujan NK, Harrison I, et al. Balancing hydropower and biodiversity in the Amazon, Congo, and Mekong. Science 2016, 351:128-129.

101. Garcìa M, Jordan C, O'Farril G, Poot C, Meyer N, Estrada N, Leonardo R, Naranjo E, Simons Á, Herrera A, et al. Tapirus bairdii. The IUCN Red List of Threatened Species 2008: e.T21471A9284327. 2008.

102. Ng HH. Hemibagrus microphthalmus. The IUCN Red List of Threatened Species 2010: e.T168431A6490953. 2010.

103. Hogan Z, Jensen O. Hucho taimen. The IUCN Red List of Threatened Species 2013: e.T188631A22605180. 2013.

104. Stone R. The last of the leviathans. Science 2007, 316:1684-1688.

105. Turvey ST, Risley CL, Moore JE, Barrett LA, Hao YJ, Zhao XJ, Zhou KY, Wang D. Can local ecological knowledge be used to assess status and extinction drivers in a threatened freshwater cetacean? Biological Conservation 2013, 157:352-360.

106. Dunham KM, Ghiurghi A, Cumbi R, Urbano F. Human-wildlife conflict in Mozambique: a national perspective, with emphasis on wildlife attacks on humans. Oryx 2010, 44:185-193.

107. Santiapillai C, de Silva M. Status, distribution and conservation of crocodiles in Sri Lanka. Biological Conservation 2001, 97:305-318.

108. Choudhury BC, de Silva A. Crocodylus palustris. The IUCN Red List of Threatened Species 2013: e.T5667A3046723. 2013.

109. Nel J, Somers M. The status of otters in Africa: an assessment. In: VIIth International Otter Symposium. Trebon, Czech Republic. IUCN Otter Specialist Group Bulletin (19A); 1998, 258266.

110. Christie T, Steininger MK, Juhn D, Peal A. Fragmentation and clearance of Liberia's forests during 1986-2000. Oryx 2007, 41:539-543.

111. Norris K, Asase A, Collen B, Gockowksi J, Mason J, Phalan B, Wade A. Biodiversity in a forestagriculture mosaic - The changing face of West African rainforests. Biological Conservation 2010, 143:2341-2350.

112. Ransom C, Robinson PT, Collen B. Choeropsis liberiensis. The IUCN Red List of Threatened Species 2015: e.T10032A18567171. 2015.

113. Scholz NL, McIntyre JK. Chemical pollution. In: P. CG, M. K, D. OJ, eds. Conservation of Freshwater Fishes. Cambridge, UK: Cambridge University Press; 2015.

114. Nasrollahzadeh A. Caspian Sea and its ecological challenges. Caspian Journal of Environmental Sciences 2010, 8:97-104.

115. Wang D, Turvey S, Zhao X, Mei Z. Neophocaena asiaeorientalis ssp. asiaeorientalis. The IUCN Red List of Threatened Species 2013: e.T43205774A45893487. 2013.

116. Mei ZG, Zhang XQ, Huang SL, Zhao XJ, Hao YJ, Zhang L, Qian ZY, Zheng JS, Wang KX, Wang D. The Yangtze finless porpoise: On an accelerating path to extinction? Biological Conservation 2014, 172:117-123.

117. Chen X. Biological characteristics and current situation of resource of species of Acipenseriformes. Beijing, China: Ocean Publishing House; 2007.

118. Assessment ME. Ecosystems and human well-being. Vol. 5: Island press Washington, DC; 2005.

119. Peters K, Bundschuh M, Schafer RB. Review on the effects of toxicants on freshwater ecosystem functions. Environmental Pollution 2013, 180:324-329.

120. Farkas A, Erratico C, Vigano L. Assessment of the environmental significance of heavy metal pollution in surficial sediments of the River Po. Chemosphere 2007, 68:761-768.

121. Kasymov A. Ecology of the Caspian Lake. Baku, Azerbaijan: Azerbaijan Publishing House 1994. 
122. Bickham JW, Rowe GT, Palatnikov G, Mekhtiev A, Mekhtiev M, Kasimov RY, Hauschultz DW, Wickliffe JK, Rogers WJ. Acute and genotoxic effects of Baku Harbor sediment on Russian sturgeon, Acipenser guildensteidti. Bulletin of Environmental Contamination and Toxicology 1998, 61:512-518.

123. St. Pierre R, Parauka FM. Acipenser oxyrinchus. The IUCN Red List of Threatened Species 2006: e.T245A13046974. 2006.

124. Lind PM, Milnes MR, Lundberg R, Bermudez D, Orberg J, Guillette LJ. Abnormal bone composition in female juvenile American alligators from a pesticide-polluted lake (Lake Apopka, Florida). Environmental Health Perspectives 2004, 112:359-362.

125. Yoshikane M, Kay WR, Shibata Y, Inoue M, Yanai T, Kamata R, Edmonds JS, Morita M. Very high concentrations of DDE and toxaphene residues in crocodiles from the Ord River, Western Australia: an investigation into possible endocrine disruption. Journal of Environmental Monitoring 2006, 8:649-661.

126. Charruau P, Henaut Y, Alvarez-Legorreta T. Organochlorine pesticides in nest substratum and infertile eggs of American crocodiles (Reptilia, Crocodylidae) in a Mexican Caribbean atoll. Caribbean Journal of Science 2013, 47:1-12.

127. Bouwman H, Booyens P, Govender D, Pienaar D, Polder A. Chlorinated, brominated, and fluorinated organic pollutants in Nile crocodile eggs from the Kruger National Park, South Africa. Ecotoxicology and Environmental Safety 2014, 104:393-402.

128. Abdel-moneim A, Coulter DP, Mahapatra CT, Sepulveda MS. Intersex in fishes and amphibians: population implications, prevalence, mechanisms and molecular biomarkers. Journal of Applied Toxicology 2015, 35:1228-1240.

129. Guillette LJ, Crain DA, Gunderson MP, Kools SAE, Milnes MR, Orlando EF, Rooney AA, Woodward AR. Alligators and endocrine disrupting contaminants: A current perspective. American Zoologist 2000, 40:438-452.

130. Milnes MR, Bryan TA, Medina JG, Gunderson MP, Guillette L. Developmental alterations as a result of in ovo exposure to the pesticide metabolite $p, p$ '-DDE in Alligator mississippiensis. General and Comparative Endocrinology 2005, 144:257-263.

131. Barnhoorn IEJ, Bornman MS, Pieterse GM, van Vuren JHJ. Histological evidence of intersex in feral sharptooth catfish (Clarias gariepinus) from an estrogen-polluted water source in Gauteng, South Africa. Environmental Toxicology 2004, 19:603-608.

132. Kruger T, Barnhoorn I, van Vuren JJ, Bornman R. The use of the urogenital papillae of male feral African sharptooth catfish (Clarias gariepinus) as indicator of exposure to estrogenic chemicals in two polluted dams in an urban nature reserve, Gauteng, South Africa. Ecotoxicology and Environmental Safety 2013, 87:98-107.

133. Lockwood JL, Hoopes MF, Marchetti MP. Invasion ecology. Chichester, UK: John Wiley \& Sons; 2013.

134. Allendorf FW, Lundquist LL. Introduction: Population biology, evolution, and control of invasive species. Conservation Biology 2003, 17:24-30.

135. Gurevitch J, Padilla DK. Are invasive species a major cause of extinctions? Trends in Ecology \& Evolution 2004, 19:470-474.

136. Vander Zanden MJ, Casselman JM, Rasmussen JB. Stable isotope evidence for the food web consequences of species invasions in lakes. Nature 1999, 401:464-467.

137. Ivanov VP, Kamakin AM, Ushivtzev VB, Shiganova T, Zhukova O, Aladin N, Wilson SI, Harbison GR, Dumont HJ. Invasion of the Caspian Sea by the comb jellyfish Mnemiopsis leidyi (Ctenophora). Biological invasions 2000, 2:255-258.

138. Dmitrieva L, Harkonen T, Baimukanov M, Bignert A, Jussi I, Jussi M, Kasimbekov $Y$, Verevkin $\mathrm{M}$, Vysotskiy $\mathrm{V}$, Wilson $\mathrm{S}$, et al. Inter-year variation in pup production of Caspian seals Pusa caspica 2005-2012 determined from aerial surveys. Endangered Species Research 2015, 28:209-223. 
139. Welcomme RL, Vidthayanon C. The impacts of introductions and stocking of exotic species in the Mekong Basin and policies for their control: Mekong River Commission Cambodia; 2003.

140. Ludwig A. A sturgeon view on conservation genetics. European Journal of Wildlife Research 2006, 52:3-8.

141. Allan D, Esselman P, Abell R, Mclntyre P, Tubbs N, Biggs H, Castello L, Jenkins A, Kingsford R. Protected areas for freshwater ecosystems: essential but underrepresented. In: Mittermeier RA, Farrell TA, Harrison IJ, Upgren AJ, TM B, eds. Fresh water: the essence of life. Arlington: CEMEX \& ILCP; 2010, 155-178.

142. Lawler JJ, Aukema JE, Grant JB, Halpern BS, Kareiva P, Nelson CR, Ohleth K, Olden JD, Schlaepfer MA, Silliman BR, et al. Conservation science: a 20-year report card. Frontiers in Ecology and the Environment 2006, 4:473-480.

143. Monroe JB, Baxter CV, Olden JD, Angermeier PL. Freshwaters in the Public Eye: Understanding the Role of Images and Media in Aquatic Conservation. Fisheries 2009, 34:581-585.

144. Abell R, Lehner B, Thieme M, Linke S. Looking Beyond the Fenceline: Assessing Protection Gaps for the World's Rivers. Conservation Letters 2016: doi: 10.1111/conl.12312.

145. Barrett J, Ansell D. The practicality and feasibility of establishing a system of freshwater protected areas in the Murray-Darling Basin. In: Proceedings of the World Congress on Aquatic Habitat Congress; 2003, 601-613.

146. Kalinkat G, Cabral JS, Darwall W, Ficetola GF, Fisher JL, Giling DP, Gosselin M-P, Grossart H-P, Jähnig SC, Jeschke JM, et al. Flagship umbrella species needed for the conservation of overlooked aquatic biodiversity. Conservation Biology 2016:http://dx.doi.org/10.1111/cobi.12813.

147. Darwall WRT, Holland RA, Smith KG, Allen D, Brooks EGE, Katarya V, Pollock CM, Shi YC, Clausnitzer V, Cumberlidge $\mathrm{N}$, et al. Implications of bias in conservation research and investment for freshwater species. Conservation Letters 2011, 4:474-482.

148. Di Minin E, Moilanen A. Improving the surrogacy effectiveness of charismatic megafauna with well- surveyed taxonomic groups and habitat types. Journal of Applied Ecology 2014, 51:281-288.

149. Zacharias MA, Roff JC. Use of focal species in marine conservation and management: a review and critique. Aquatic Conservation-Marine and Freshwater Ecosystems 2001, 11:5976.

150. Caro TM. Umbrella species: critique and lessons from East Africa. Animal Conservation 2003, 6:171-181. 